\title{
Research on the bottleneck of Outstanding Mechanical Engineering Talents Training Pattern
}

\author{
Yali Hou ${ }^{1}$, Changhe $\mathrm{Li}^{* 1}$, Hengshan Yang ${ }^{* 2}$, Yong Yang ${ }^{1}$, Yanbin Zhang ${ }^{1}$ and Dongzhou Jia ${ }^{2}$ \\ ${ }^{1}$ School of Mechanical Engineering, Qingdao University of Technology \\ Qingdao, China 266520 \\ ${ }^{2}$ Inner Mongolia University for Nationalities \\ Tongliao, China 028000 \\ *Corresponding author. Tel: +86-532-68052760; Fax: +86-532-85071286 \\ E-mail address: sy_lichanghe@163.com ${ }^{* 1} ; 13947519082 @ 163$. com $^{* 2}$
}

\begin{abstract}
The necessity of studying the outstanding mechanical engineering talents training pattern is analyzed, and a training goal of outstanding plan is established as well as a new higher engineering education system. The implementation task of outstanding plan is analyzed, and a new college-enterprise joint cooperation mechanism and applied talents training pattern is established. The bottleneck of deficient innovation capacity in outstanding engineering talents training pattern is analyzed, and case-type teaching pattern, enterprise demand-oriented training pattern as well as an innovative \& entrepreneurial education patterns is constructed. Based on clear understanding of educational philosophy and talents training objective, "three-level progressive in-class project system, three-stair-type extracurricular scientific and technological innovation platform and tricyclic complementary college-enterprise joint "three-threethree" outstanding engineering talent training pattern should be deeply studied to construct process-based hierarchical graded teaching evaluation standard which can comprehensively assess students' knowledge, ability and quality and form accurate output-oriented ability achievement evaluation system with controllable quantification and multi-channel feedback", and on this basis, a new outstanding engineering talent training pattern taking professional theoretical knowledge learning, comprehensive engineering quality and innovative \& entrepreneurial ability as training objectives should be established.
\end{abstract}

Keywords-outstanding engineering talents training; bottleneck; innovation; college-enterprise collaboration

\section{INTRODUCTION}

Cultivation of engineering technical talents is a necessary guarantee for developing strategic emerging industries and constructing new-type industrialized country. Higher engineering education aims at cultivating high-quality and high-level application-oriented engineering technical talents, and rapid development of higher engineering education can narrow the gap between China and world developed countries so as to provide talent guarantee for new-type industrialized development and strategic emerging industries in China.

Cultivation of engineering technical talents is an intellectual guarantee for constructing an innovation-originated nation. Strengthening cultivation of innovation capability of engineering technical talents is source power for rapid development of science \& technology and industrial economy, implementing Outstanding Plan is a powerful measure to realize this goal, and reform of higher engineering education can significantly improve practical and innovation abilities of engineering technical talents.

Cultivation of engineering technical talents is an inevitable requirement for strengthening China's comprehensive economic strength and further fusing into global economic integration. To improve economic competitiveness of China in the world must improve innovative competiveness of engineering technical talents, reinforce expenditure support and through reform of higher engineering education, cultivate batches of high-quality engineering technical talents who are proficient with international economic rules, adapt to international open communication and own international competitive advantages [1].

\section{ESTABLISH TRAINING GOAL OF OUTSTANDING PLAN}

\section{A. Build a New Higher Engineering Education System}

Aiming at cultivating engineering talents with engineering practice ability and strong innovation capability, a new higher engineering education system with Chinese characteristics should be established through implementing Outstanding Plan and reforming and innovating higher engineering educational pattern.

\section{B. Cultivate outstanding engineers with strong practical and innovation capabilities}

Economic and social development can be boosted by cultivating high-quality outstanding engineers with strong practical and innovation capabilities so as to accelerate construction progress of modernized innovation-type industrialized country and elevate comprehensive national strength and international competitiveness. 


\section{IMPLEMENTATION TASK OF OUTSTANDING PLAN}

\section{A. Establish new college-enterprise joint cooperation} mechanism

According to training objective and orientation of outstanding engineers, in-depth college-enterprise cooperation system can be established. College-enterprise cooperation is the core content of Outstanding Plan, and the whole process of enterprises participating in students cultivation provide real engineering practical environment for students and strengthen students' engineering practice and innovation abilities. Participation of colleges and universities into development and research of new technologies of enterprises will boost elevation of enterprise productivity and finally realize the win-win pattern between colleges and enterprises.

\section{B. Applied talents training pattern}

Present teaching method adopted by Chinese colleges and universities in aspect of talents cultivation is mainly knowledge infusion, and Outstanding Plan is implemented to change students' learning status in which theory is given with much more attention than practice so as to enhance practical teaching links. Diversity of teaching methods can be realized to change single classroom teaching method, and students' learning initiative can be motivated by adding projects, case teaching methodology, etc. In practical links, practicality of engineering education is boosted, and teaching methods and teaching contents of collective learning phase should be adopted to substantially improve students' practice and innovation abilities and consolidate their working experience in enterprises [2].

\section{Create teaching staffs with strong engineering background}

The situation in which engineering practice of college teachers occupied in engineering education should be changed, number of teachers with engineering practice background should be enlarged, in-college teachers should be encouraged to take a temporary post for exercising themselves in enterprises, and meanwhile, senior technicians from cooperative enterprises should be recruited to act as part-time teachers in Outstanding Plan. High-quality "dual teacher type" teaching faculty can be organized to guarantee talents training quality of Outstanding Plan.

\section{Open wider to the outside world}

In order to adapt to strategic requirement for enterprises to "step out" and enhance cooperation with foreign colleges especially foreign industrial circles, a batch of first-front technical talents with trans-cultural communication and cooperation can be cultivated.

\section{THE BOTTLENECK OF DEFICIENT INNOVATION CAPACITY IN OUTSTANDING ENGINEERING TALENTS TRAINING PATTERN}

Through development over the years, Chinese Outstanding Engineering Talents Training has achieved gratifying performance, but academic education-centered talents training pattern fails to really solve the talents training problem. Latest report of Ministry of Industry and Information shows that even though absolute quantity of Chinese engineering talents is enormous, as engineering talent structural contradiction becomes prominent with a lack of high-level, composite type and leading talents, at present, national senior engineering talent gap reaches as high as 5 million. Specifically speaking, the problems existing in outstanding engineering talents training are mainly manifested in the following points:

Training standard of Outstanding Plan can't highlight characteristics of college talent training and practical links are unreasonably set, which can't promote elevation of engineering practical capability and directly affect quality of outstanding talents.

Although proportion of engineering practices in teaching reform is large, how to balance the contradiction between professional theory and engineering practice and that between thick foundation and wide caliber within limited time needs further research.

\section{A. College-enterprise joint training pattern with deep} interaction and integration between in-college learning and enterprise practice has not been established

College-enterprise cooperation depth is not enough, practical ability training in Outstanding Plan has broken through the past simplified "dipping in and out" enterprise practice but it lacks standard reciprocal and win-win cooperation pattern, and enterprise initiative is not high so it's difficult to establish long-acting cooperation mechanism.

The teaching system integrating teaching, scientific research and production which meets professional certification requirements of "Washington Accord" should be established and be further perfected and improved.

To deepen teaching reform by centering on ability and solve the bottleneck of transforming talents training pattern from "knowledge classroom" into "ability classroom" needs to reconstruct reforming process of teaching contents and patterns of series of curriculums in machine design \& manufacturing and its automation specialty.

Accurate ability achievement evaluation system which orients at output with controllable quantification and multichannel feedback should be further refined and perfected.

With improving students' comprehensive engineering quality and innovation \& entrepreneurial ability taken as objective and based on OBE concept, multiple links of students learning and practice are incorporated into curriculum assessment index system, students' knowledge, ability and quality should be comprehensively assessed and whole-process management of curriculum learning should be implemented so as to construct a process-based ability achievement evaluation method which orients at output with controllable quantification[3]. Plan

Role Played by Talents Training Pattern in Outstanding 
Talents training pattern is just like a "baton" which affects orientation and development trend of talents training and decide whether final goal of talents training can be achieved. Education in Outstanding Plan has higher requirements for engineering quality, practicality and application than the past curriculum0centered education, participation into enterprises is added during students training process, and these constitute a breakthrough of previous classroom education. This breakthrough has proposed higher and newer requirements for talents training pattern of Outstanding Plan, reasonable talents training pattern can make engineer training more planned so as to guarantee talents training quality and cultivate talents with both high engineering ability and engineering quality. Therefore, success or failure of talents training pattern decides whether Outstanding Plan can cultivate engineering technical talents with solid engineering background and strong innovation capacity [4].

\section{Several Constructed Applied-type Talents Training Patterns}

Chinese colleges and universities can be basically divided into two types - academic research type and application type, the latter has gradually replaced the former and become the mainstream, and colleges and universities occupied in higher engineering education are basically application type. This trend is the transition of higher education from "elite education" into "mass education" as often mentioned by scholars.

\section{B. Case-type teaching and training pattern}

Case-type teaching pattern originated from MBA teaching in Harvard Business College in the 1920s, and later then, it was gradually applied to all levels of teaching and China started researches on case-type teaching pattern since the 1990s. General procedures of case teaching are: the teacher selects relevant typical cases before teaching according to training objective and curriculum requirements and by combining students' actual situation and then sets students' learning objectives. During learning process, students will carry out discussion about cases provided by the teacher in groups. Subsequently, the teacher will summarize different opinions of these students, analyze difference and internal relations between these opinions and guide students to summarize and give conclusions so as to finally achieve the goal of mastering knowledge points.

Case-type teaching pattern can motivate students' learning initiatives and make teaching process more vivid and intuitive, it can transit original "teacher teaching and students listening" into everyone participation, and in this way, heads can be put together to promote joint discussion. Higher engineering specialty always sets curriculums for different subjects with problems like content separation, students' lack of understanding of engineering background and insufficient engineering practice and training, etc. Introducing case-type teaching pattern in engineering education can help students to transform principle of theoretical knowledge into students' engineering ability and provide idea for students to solve practical problems.

\section{Enterprise demand-oriented training pattern}

As Chinese colleges and universities started large-scale enrollment expansion in 1999, a large number of college graduates enter the market, but the contradiction between employment demand for college graduates and talent demand of employers has become an urgent problem which must be faced by higher education.

With rapid economic development, the market needs more and more applied talents, talents cultivated under original academic research-type talents training pattern of colleges have solid professional knowledge and certain research abilities, but these knowledge and abilities lack correlation with practical industrial production and engineering practicing experience. To overcome this talents training weakness, cultivate talents in urgent need in the market and change the current situation of employment difficulty of students, colleges must understand trends of the market and enterprise demand for talents to establish an enterprise demand-oriented training pattern.

Optimize curriculum system and formulate enterprise demand-oriented talents training scheme. To cultivate applied talents and prevent talents training from being disjointed from enterprise demand, colleges must firstly formulate enterprise demand-oriented talents training scheme which is specific implementation scheme formulated to realize talents training goal including setting of teaching objectives, setting of curriculum system, teaching progress arrangement, teaching evaluation system, etc.

Practical teaching is an important part of curriculum system in higher teaching process and it's especially of significance to colleges implementing applied-type talents training in Outstanding Plan. Long-term practice certifies that it's impossible for college students to obtain comprehensive practical ability and spirit of innovation only by relying on classroom teaching and theoretical teaching, but instead, they need training in practical teaching link. The effect of practical teaching on this aspect can't be realized by theoretical teaching, and this is where core value of practical teaching lies. Practical teaching can develop students' potentials to the greatest extent, cultivate students' comprehensive ability and spirit of innovation in aspects of utilizing knowledge, creating knowledge and devoting to social practice and provide necessary conditions for students to comprehensively improve their high quality and smoothly enter the society.

Outstanding Plan takes strengthening practical ability as core of outstanding engineer cultivation. Original practical reaching has problems like few credit hours, practical contents separating from actual demand, "dipping in and out" practicing process, etc., all of which have affected training of students' practical abilities and affected their employment competitiveness. Setting of practical teaching system needs to associate theoretical curriculums with practical curriculums and practical links with enterprise production, and not only credit hours of practical links should be increased but also attention should be paid to implementation mode and form.

Practical teaching system is divided into three levels: cognitive experiment, foundation engineering practice and comprehensive practice. Students' engineering practice 
abilities can be exercised and enhanced step by step through the three levels. "Project-driven" and "case-driven" practical teaching pattern should be implemented to provide practical problems in enterprise production for students as projects or cases so that students can autonomously complete practical contents in ways of completing projects or analyzing cases so as to substantially improve their abilities of solving practical engineering problems.

\section{Strengthen training pattern of innovative \& entrepreneurial education}

Innovative \& entrepreneurial education patterns originated from America in the 1950s, subsequently, it was widely implemented in various countries in the world, and it exerts enormous effect in solving national employment problems. Influenced by original academic research-type educational pattern, Chinese innovative \& entrepreneurial education has a late start. In Opinions about Vigorously Boosting College Innovative \& entrepreneurial Education and College Students' Self-employment in 2010, the Ministry of Education pointed out, "implementing innovative \& entrepreneurial education in college students and actively encouraging college students to become self-employed constitute a significant strategic measure for education system to implement in-depth study and practice of scientific outlook on development and serve innovation-type country construction, an important path to deepen higher educational teaching reform and cultivating students' spirit of innovation and practice capability as well as an important measure of promoting full employment of college graduates". Report on the 18th National Congress of the Communist Party of China definitely put forward implementing innovation-driven development strategies. In 2014, Premier Keqiang Li highlighted the opinion "mass entrepreneurship and innovation" for the first time. These policy orientations play guiding roles in development of higher education. To adapt to the historical background, colleges should take initiatives in reform and take cultivating talents with innovative \& entrepreneurial quality as one of reforming objectives. Implementing Outstanding Plan and cultivating applied talents constitute one of important paths to realize innovative \& entrepreneurial educational objectives [5].

Innovative \& entrepreneurial education injects innovative \& entrepreneurial elements in higher education, and taking cultivating students' comprehensive quality in aspects of consciousness of innovation, creation enthusiasm, spirit of innovation, innovation capability, entrepreneurial quality and culture as objective, it moulds students' independent spirit of innovation and entrepreneurial personality so as to meet demand for high-quality innovative talents in social and economical transformation period.

Both innovative \& entrepreneurial education and outstanding plan take cultivating high-quality talents with practice ability as the objective and emphasize integration of theory and practice, and therefore, innovative \& entrepreneurial education should be integrated into talents training process in outstanding plan, innovative \& entrepreneurial education will keep pace with outstanding plan and jointly devote to cultivating students' innovation ability and train their entrepreneurial consciousness so that students will enjoy broader range of choices of occupation and the employment difficulty can be changed.

At present, there are mainly two patterns in Chinese college innovative \& entrepreneurial education: one is innovative \& entrepreneurial theoretical knowledge instruction, and this pattern centers on curriculums like occupational guidance and entrepreneurial guidance and provides basic theoretical knowledge about innovation and entrepreneurship. The major defect of this educational pattern lies in engaging in idle theorizing with a lack of practical training, students' learning centers on obtaining credits, so it can't exert guiding effect on students' development after graduation. The second is to carry out second-classroom entrepreneurial practice activity. This pattern centers on students participation in all kinds of innovation competition, visit activities and lectures and forums, although students have stepped out of the classroom, their individualized demand can't be satisfied.

When formulating talents training project, colleges should combine features of innovative $\&$ entrepreneurial education and outstanding plan, integrate and perfect original curriculum system and combine innovative \& entrepreneurial curriculum with specialized curriculum system and integrate them into both the category of theoretical curriculum and specialized practical teaching. Colleges should set up innovative \& entrepreneurial basic theoretical courses for lower grade students and set up simulative practice courses among higher grade students and increase credit hours of practical links. During selection process of course contents, they should add relevant innovative \& entrepreneurial general educational curriculums to expand scope of knowledge. In order to fully exert students' subjective initiative and prevent courses from being dull, course contents should be of interestingness and avoid "duck-stuffing" teaching method. Multiple teaching methods like case teaching, heuristic teaching and project demonstration should be utilized to cultivate students' independent thinking ability. In aspect of assessment and evaluation, traditional assessment method which uses one exam paper to assess students' performance should be changed, but instead, attention should be paid to students' ability assessment, so comprehensive evaluation method should be used to boost their comprehensive development and encourage students to participate in all kinds of innovative \& entrepreneurial competitions and declare for innovative \& entrepreneurial projects.

\section{SIGNIFICANCE OF IN-DEPTH COLLEGE-ENTERPRISE COLLABORATED EDUCATION IN OUTSTANDING PLAN}

College-enterprise cooperative training pattern refers to the college-enterprise joint cultivation mechanism in which engineering technical personnel with high comprehensive quality are cultivated in order to improve students' engineering ability and innovation ability, and advantageous resources of colleges and enterprises are integrated to jointly formulate training objectives.

As educational leading edge of national advanced knowledge technology, colleges are representatives of advanced technology which possess a large number of senior talents with solid professional theoretical knowledge and new 
technological research \& development abilities and they are the places with centralized proprietary intellectual property rights. Meanwhile, colleges are generally set with high-level labs at national level and provincial level. The labs have sufficient construction expense and advanced equipment and they have advantages in aspect of new technological breakthrough and innovation [6].

Enterprises are the forefront of product production and they directly face the market, and market demand is baton of enterprise production. Enterprises own development and design personnel who are in line with the market and can master industrial development trend. Meanwhile, enterprises own real working environment which can't be given by colleges to students, and practice under real working environment helps students to adapt to requirements of working posts after graduation as soon as possible.

Colleges utilize advantageous enterprise resources to provide students with real engineering practical environment while providing theoretical learning site for students through college-enterprise cooperation [7]. Enterprises integrate talent demand into college talents training pattern through collegeenterprise cooperation so as to cultivate engineering talents whom enterprises really need and attract more excellent talents to enter enterprises. Students realize linking theory with their practice through college-enterprise cooperation in order to improve their own engineering practice ability and innovation ability and accumulate rich engineering experience for employment or entrepreneurship after graduation.

College-enterprise cooperation is the need of colleges for their own development and functional extension as well as the core element of implementing outstanding plan and realizing high-quality talents training [8]. Taking cultivating high-quality engineering talents with strong engineering ability and innovation ability and adapting to economic development as the objective, outstanding plan definitely puts forward that enterprises should deeply participate in training process and colleges should cultivate talents according to general industrial standards, which decides necessity of college-enterprise cooperation in outstanding plan.

The need of enterprises participating in college-enterprise cooperation for enhancing their research and development ability, improving production technological level and attracting high-quality engineering talents is the internal need for enterprise survival and development. In college-enterprise cooperation, colleges recruit engineers with rich experience in enterprises to act as extracurricular tutors of students, and enterprises provide students with production links needed in practice, arrange students to participate in production practice, attract students to participate in project research and development of new enterprise technologies and improvement of new industry and attract graduates in outstanding plan to take posts in enterprises. Enterprise competition is talent competition, high-quality talents constitute dynamic source for enterprises to elevate technological level, and enterprises in college-enterprise cooperation obtain profits while providing students with practical conditions, which promotes enterprise technological reform and enhancement of their independent development ability.

\section{CONCLUSION}

Outstanding plan stresses on establishing new mechanism of college-enterprise joint talents training, therefore, collegeenterprise cooperation is core content of outstanding plan, and successful establishment of college-enterprise cooperation mode is the key for smooth implementation of outstanding plan. Subjects of college-enterprise cooperation involve three aspects - colleges, enterprises and students, and outstanding plan can be boosted towards development in depth and breadth only by realizing mutual benefit and win-win pattern of the three aspects. And on in this way can the objective of outstanding plan to cultivate and create applied talents who can adapt to economic development requirements with strong innovation ability. Implementation of outstanding plan accords with principles of "industrial guidance, college-enterprise cooperation, classified implementation and diversified forms". Implementation of outstanding plan taken as the sally port, engineering educational reform and innovation are promoted so as to comprehensively improve talents training quality in Chinese engineering education. Efforts should be put to construct socialist modernized higher engineering education system with world advanced level and Chinese characteristics to facilitate China to step from an engineering educational country towards a powerful engineering educational country. Thus it can be seen that construction of talents training pattern of outstanding plan must be based on engineering practice, and take improvement of engineering technology as the principal line and college-enterprise cooperation as implementation path.

Based on clear understanding of educational philosophy and talents training objective, "three-level progressive in-class project system, three-stair-type extracurricular scientific and technological innovation platform and tricyclic complementary college-enterprise joint "three-three-three" outstanding engineering talent training pattern should be deeply studied to construct process-based hierarchical graded teaching evaluation standard which can comprehensively assess students' knowledge, ability and quality and form accurate output-oriented ability achievement evaluation system with controllable quantification and multi-channel feedback", and on this basis, a new outstanding engineering talent training pattern taking professional theoretical knowledge learning, comprehensive engineering quality and innovative \& entrepreneurial ability as training objectives should be established.

\section{ACKNOWLEDGMENT}

This research was financially supported by the teaching reform research project of higher education in Shandong province (Z2016Z011; 2012042 and 2015M087)

\section{REFERENCES}

[1] Changhe Li, Yali Hou, and Jianjun Yang, "Research on Project-Driven Teaching Method of Technology of Mechanical Manufacture Based on Ability Training," International Journal of Information and Education Technology, Vol. 7, No. 6, 2017: 474-478

[2] Y. L. Hou and C. H. Li, "The research and practice on the integrated optimization of the machinery manufacturing joint curriculum group platform," Advances in Social and Behavioral Sciences, vol.6, pp.1016,2014 . 
[3] R. F. Wang, "Combination of traditional teaching and interactive teaching," The Border Economy and Culture, vol.12, pp.63-72, 2011.

[4] C. H. Li, Y. L. Hou, J. J. Yang, H. B. Lan, "The Construction of practical teaching system and innovative talent training mode in the fundamental course of mechanic manufacturing," Advances in Education Research, vol.54, pp.7-12,2014.

[5] P. Różewski, O. Zaikin, "Integrated mathematical model of competence-based learning-teaching process," Bulletin of the Polish Academy of Sciences Technical Sciences, vol. 63, pp. 245-259, 2015.
[6] F. Peng, F. X. Xiao, and Y. L. Wang, "Improving experiment examination method and Cultivating innovative talents," The journal of Science and education, vol.12, pp.192, 2008.

[7] L. P. Gu, "Practical teaching system construction in higher vocational colleges," China's higher education research, vol.11, pp.67-68, 2005.

[8] J. Jiang, "Mechanical manufacturing basis curriculum project teaching method in the exploration and practice," Journal of anhui technical college of electrical engineering, vol.4, pp.95-98, 2005. 